\title{
Muscular atrophy, impaired epithelial autophagy and UCHL1 increase in androgen-deficient cauda epididymis
}

\author{
Fabiane de Santi ${ }^{1}$, Isadora Dantas Lunardi ${ }^{2}$, Flávia Luciana Beltrame ${ }^{1}$, Paulo Sérgio Cerri ${ }^{2}$ and \\ Estela Sasso-Cerri² \\ ${ }^{1}$ Department of Morphology and Genetics, Federal University of São Paulo (UNIFESP/EPM), São Paulo, São Paulo, \\ Brazil and ${ }^{2}$ Laboratory of Histology and Embryology, Department of Morphology, Genetics, Orthodontics and \\ Pediatric Dentistry, Dental School - São Paulo State University (UNESP/FOAr), Araraquara, São Paulo, Brazil \\ Correspondence should be addressed to E Sasso-Cerri; Email: estela.sasso@unesp.br
}

\begin{abstract}
In epididymis, cimetidine induces androgenic failure due to reduced sex hormone-binding globulin stromal levels and blockade of androgen receptor (AR) nuclear import. UCHL1, a hydrolase of ubiquitin-proteasome system (UPS), seems to play a role in autophagy and apoptotic pathway. However, the role of UPS and autophagy in epididymis has not been clarified. We evaluated UCHL1 and autophagy in epididymal cauda epithelium under androgenic deficiency induced by cimetidine, focusing on the interplay among these processes and apoptosis. The integrity of epididymal muscular layer was also evaluated. Male rats received cimetidine (CMTG) or saline (CG). Seminal vesicles were weighed, the expression of androgen-responsive genes Crisp1 and connexin 43 (Cx43) in cauda epididymis was evaluated, and cauda fragments were processed for light and transmission electron microscopy. The epithelium height and muscular thickness were measured. TUNEL, immunohistochemistry for caspase-3 and Cx43, and immunofluorescence for AR, BCl-2, UCHL1, MAP LC3A, and p62/SQSTM1 (autophagic markers) were performed. Bcl-2, UCHL1, and Cx43 were detected by Western blot. In CMTG, the reduction in seminal vesicles weight accompanied by downregulation of Crisp1 and Cx43 confirmed epididymal androgenic failure. These results were associated with muscular atrophy, apoptosis and weak Cx43 and AR immunoexpression, supporting the androgenic dependence of muscular integrity. The high UCHL1 levels and reduction in Bcl-2 reinforce UCHL1 role in epithelial cells death. The intense immunoexpression of LC3A and p62/SQSTM1 indicates autophagic disturb, which in association with high UCHL1 levels, points to a role of UPS and autophagy in the regulation of epididymal epithelial cells viability under androgenic control.

Reproduction (2020) 159 693-705
\end{abstract}

\section{Introduction}

Spermatozoa storage in cauda epididymis depends on epithelial activity, which creates a microenvironment responsible for the maintenance of sperm quiescence (Cooper 1986, Cornwall 2009, Robaire \& Hinton 2015). The epithelial cells are regulated by dihydrotestosterone (DHT) (Wong \& Yeung 1978, Wong et al. 1978, Moore \& Bedford 1979), a biologically active androgen in epididymis that binds to androgen receptor (AR) and regulates the expression of genes involved in cell survival (Ezer \& Robaire 2003, Robaire \& Hamzeh 2011). Thus, androgen withdrawal induces apoptosis in all epididymal regions (Fan \& Robaire 1998, Kempinas \& Klinefelter 2014) and impairs sperm reproductive competence due to alterations in sperm storage in cauda epididymis (Orgebin-Crist et al. 1975, Foldesy \& Bedford 1982, Robaire \& Hinton 2002). Besides androgens, several processes maintain sperm quality in epididymis and studies have suggested that extracellular ubiquitination may be involved in the elimination of defective spermatozoa (Sutovsky et al. 2001, Sutovsky 2003, Baska et al. 2008, Eskandari-Shahraki et al. 2013). Ubiquitination is a process in which the covalent attachment of a ubiquitin molecule (Kleiger \& Mayor 2014) generates a signal that directs the cellular components for destruction in cellular proteolytic machinery: the ubiquitin-proteasome system (UPS) or in the autophagic pathway (Shaid et al. 2013, Ji \& Kwon 2017). This process is regulated by deubiquitinating enzymes (DUBs), which are responsible for disassembling ubiquitin-substrate covalent link in order to edit or remove ubiquitin signal (Komander et al. 2009). Thus, DUBs are crucial regulators of almost all cellular process, such as transcription, cell cycle, and apoptosis (Amerik \& Hochstrasser 2004). The ubiquitin carboxyl-terminal hydrolase L1 (UCHL1), a protein gene product 9.5, is a DUB involved in both deubiquitination and ubiquitination processes (Liu et al. 2002). Although UCHL1 has been demonstrated in testes (Kwon et al. 
2004a) and in epithelial cells of caput and cauda epididymis (Santamaria et al. 1993, Kwon et al. 2006), the role of this hydrolase in these organs has not yet been clarified. However, studies have confirmed the role of UCHL1 in the molecular regulation of cell death, since different tumors present low levels of this enzyme (Wang et al. 2008, Li et al. 2010, Ummanni et al. 2011). The efferent duct ligation in mice lacking UCHL1 failed to induce apoptosis in caput epididymis epithelium (Kwon et al. 2006). Moreover, in cryptorchid mice lacking (Kwon et al. 2004b) or overexpressing (Wang et al. 2006) UCHL1, the testis shows resistance to apoptosis or high germ cell death index, respectively. A directly proportional correlation between UCHL1 and germ cell death has also been demonstrated in testes of rats treated with the antidepressant fluoxetine (Câmara et al. 2019). Besides apoptosis, UCHL1 is involved in the regulation of autophagic flux, since pharmacological inhibition of this enzyme results in activation of the autophagic pathway in oligodendroglial cells (Cartier et al. 2012, Pukaß \& Richter-Landsberg 2015). This finding is reinforced by the fact that, either in HeLa cells (Yan et al. 2018) or in cardiac fibroblasts (Zhang et al. 2014), the overexpression of this enzyme suppresses autophagy.

During autophagy, bulks of cytoplasmic components are sequestrated into double membrane vesicles, called autophagosomes, and delivered to the lysosomes for degradation or recycling (Kaur \& Debnath 2015). The microtubule-associated protein 1A/1B-light chain (MAP LC3A) is essential for autophagosome formation due to the conjugation with phosphatidylethanolamine, forming LC3-II (Klionsky et al. 2016). LC3-II is inserted in the autophagosomal membrane, being an autophagic receptor that interact with adaptor proteins (Shaid et al. 2013). These adaptor proteins, including p62/SQSTM, can bind to ubiquitinated cargos, which are delivered to the autophagosome (Kaur \& Debnath 2015). Since p62/SQSTM1 is also degraded, this specific substrate of the autophagosome has been used to determinate the autophagic flux (Klionsky et al. 2016). Cell homeostasis and survival are maintained by autophagy (Doherty \& Baehrecke 2018). In this case, the cytoprotective effect of autophagic process is associated with the degradation of pro-apoptotic factors. When a stimulus overcomes this cytoprotective effect, cell death machinery is activated. Therefore, autophagy and apoptosis are interplayed processes, in which autophagy inhibits apoptosis and vice versa (Mariño et al. 2014).

Cimetidine is an $\mathrm{H}_{2}$ receptor antagonist used to treat gastric ulcer (Brogden et al. 1978) and different types of cancer as adjuvant therapy (Kubecova et al. 2011). Male patients treated with cimetidine have demonstrated alterations in serum testosterone levels (Wang et al. 1982), gynecomastia (Spence \& Celestin 1979), and reduction in sperm concentration (Van Thiel et al.
1987). Studies have indicated that cimetidine binds to AR, antagonizing the androgen function in kidney cells, prostate and pituitary (Funder \& Mercer 1979, Winters et al. 1979, Knigge et al. 1983). Moreover, rats treated with cimetidine have demonstrated reduced serum testosterone levels (Beltrame et al. 2015, 2019, de Santi et al. 2018) associated to changes in the seminiferous epithelium (Sasso-Cerri \& Miraglia 2002, Sasso-Cerri \& Cerri 2008, Beltrame et al. 2011, 2019, Beltrame \& Sasso-Cerri 2016) and sperm parameters (Beltrame et al. 2019). In epididymis, cimetidine reduces sex hormone-binding globulin (SHBG) levels and impairs the AR nuclear import (de Santi et al. 2018), leading to epithelial cells apoptosis and confirming that this drug is an androgen disrupter in the male reproductive system. This drug also induces apoptosis in peritubular myoid cells (França et al. 2000, Sasso-Cerri \& Miraglia 2002), testicular vascular smooth muscle cells (Beltrame et al. 2012), and vas deferens muscular layer (Koshimizu et al. 2013), pointing to a sensibility of smooth muscle to androgen deficiency. It is known that the contractility of the smooth muscle layer that surrounds epididymal epithelium contributes to the movement of spermatozoa along the epididymis (Robaire \& Hinton 2015, Elfgen et al. 2018). Therefore, the regulation of the epididymal smooth muscle contraction by paracrine and endocrine factors (Elfgen et al. 2018), such as androgens (Sujarit \& Pholpramool 1985), is essential for sperm maturation and storage (Elfgen et al. 2018). Here, we investigated the integrity of cauda epididymis muscular layer under androgenic deficiency induced by cimetidine. Since the role of ubiquitination and autophagy in epididymis as well as the hormonal control of these processes have been poorly addressed, the immunoexpression of UCHL1 and autophagic markers was evaluated in the androgen-deficient epididymal epithelium, focusing on the interplay among apoptosis, ubiquitination and autophagy.

\section{Materials and methods}

\section{Animal procedures}

The protocol regarding animal use and experimental procedures was approved by the Ethical Committee for Animal Research of São Paulo State University (UNESP/FOAr; CEUA 28/2014).

Ten adult Holtzman male rats 100 days old were maintained in polypropylene cages under standard light conditions $(12 \mathrm{~h}$ light: $12 \mathrm{~h}$ darkness cycle) at controlled temperature $\left(23 \pm 2{ }^{\circ} \mathrm{C}\right)$ and humidity $(55 \pm 10)$, with water and food ad libitum. The animals from cimetidine group (CMTG; $n=5)$ received daily intraperitoneal injections of cimetidine (Hycimet, Hypofarma, Ribeirão das Neves, Brazil) $100 \mathrm{mg} / \mathrm{kg}$ of body weight (Beltrame et al. 2011, 2012, 2015, 2019, Koshimizu et al. 2013, de Santi et al. 2018), while the animals from control group $(C G=5)$ received saline by the same route. The animals 
were treated for 52 consecutive days, period that induces testicular changes (França et al. 2000, Sasso-Cerri \& Miraglia 2002, Sasso-Cerri \& Cerri 2008, Beltrame et al. 2011, 2012) as well as androgenic failure in cauda epididymis (de Santi et al. 2018). After treatment, the animals were anesthetized with $80 \mathrm{mg} / \mathrm{kg}$ bw of ketamine hydrochloride (Francotar, Virbac do Brasil Ind. Com. Ltda, Jurubatuba, Brazil) and $8 \mathrm{mg} / \mathrm{kg}$ BW of xylazine hydrochloride (Virbaxyl; Virbac do Brasil Ind. Com. Ltda Jurubatuba, Brazil). In order to obtain identical halves, each cauda epididymis was sectioned in the sagittal plane. The halves of right cauda epididymis were fixed for histological analyses and embedded in glycol methacrylate (historesin) or paraffin. One half of left cauda epididymis was collected and stored at $-80^{\circ} \mathrm{C}$ for Western blot analysis. Fragments of the other half were collected for Transmission Electron Microscopy (TEM) or immediately immersed in RNA Keeper stabilizing reagent (LGC Biotecnologia; Cotia, Brazil; 14-0002-01) for real time PCR. The seminal vesicles were removed and weighed.

\section{Histological procedures for light microscopy}

Cauda epididymis of CG and CMTG were fixed for $48 \mathrm{~h}$ in $4 \%$ formaldehyde buffered at $\mathrm{pH} 7.4$ with $0.1 \mathrm{M}$ sodium phosphate, dehydrated in ethanol, and embedded in glycol methacrylate (historesin) or paraffin. Morphological analyses were performed in 5- $\mu \mathrm{m}$-thick historesin sections stained with H.E (Cerri \& Sasso-Cerri 2003). The paraffin sections were submitted to TUNEL (TdT-mediated dUTP-biotin Nick End Labeling) method and immunofluorescence reactions.

In an attempt to maintain a standardized analysis, according to our previous study (de Santi et al. 2018), only the proximal region of cauda epididymis (Reid \& Cleland 1957, Robaire \& Hermo 1988), corresponding to segments 15 and 16 (Domeniconi et al. 2016), was analyzed in this study.

\section{Transmission Electron Microscopy (TEM)}

Fragments of cauda epididymis were fixed for $16 \mathrm{~h}$ in a mixture of freshly prepared $4 \%$ formaldehyde and $5 \%$ glutaraldehyde buffered at $\mathrm{pH} 7.2$ with $0.1 \mathrm{M}$ sodium cacodylate. After washing in $0.1 \mathrm{M}$ sodium cacodylate at $\mathrm{pH} 7.2$, the tissue fragments were transferred to sodium cacodylate-buffered $1 \%$ osmium tetroxide at $\mathrm{pH} 7.2$ for $1 \mathrm{~h}$, immersed in $2 \%$ aqueous uranyl acetate for $1.5 \mathrm{~h}$, dehydrated in graded concentrations of ethanol, treated with propylene oxide, and then embedded in Araldite (Beltrame et al. 2012, 2015). Semithin sections stained by $1 \%$ toluidine blue solution were used for morphological analysis and suitable regions were carefully selected for trimming of the blocks. Ultrathin sections were collected on grids, stained in alcoholic 2\% uranyl acetate and lead citrate, and examined in a transmission electron microscope (Tecnai G2 Spirit, FEl Company).

\section{Epithelium height and muscular layer thickness}

In three non-serial sections stained with H.E or Masson's trichrome, ten sections of epididymal ducts were captured, totalling 30 sections per animal. The images were captured using a DP-71 camera attached to Olympus BX-51 microscope. In each duct stained with H.E., the epithelial height was measured from the cell base (in contact with the basement membrane) to the apical surface, excluding the stereocilia. In the sections stained with Masson's trichrome, the thickness of the smooth muscle layer surrounding the epididymal epithelium was also measured. Two measurements of epithelium and muscular layer were performed in each duct section, totalling 60 measurements per animal, using the analysis system Image-Pro Express 6.0 (Olympus).

\section{TUNEL method}

TUNEL method was performed as previously described (Sasso-Cerri \& Miraglia 2002, Beltrame et al. 2011, 2012) and according to the ApopTag Peroxidase In Situ Kit (Millipore) manufacturer's instructions.

The sections were treated with proteinase K (SigmaAldrich) and the endogenous peroxidase was inactivated. The sections were incubated with terminal deoxynucleotidyl transferase $(\mathrm{TdT})$ for $1 \mathrm{~h}$ at $37^{\circ} \mathrm{C}$. After incubation with anti-digoxigenin peroxidase, the reaction was revealed with 3,3'-diaminobenzidine (DAB: Sigma-Aldrich) and counterstained with Carazzi's haematoxylin. Sections used as negative controls were incubated in a TdT-free solution. In four non-serial sections per animal, the number of TUNEL-positive smooth muscle cells was quantified in a total standardized perimeter of $3000 \mu \mathrm{m}$ and the number of positive cells per micrometre was obtained.

\section{Immunofluorescence and immunohistochemistry reactions}

PGP 9.5 (UCHL1), MAP LC3A, p62/SQSTM1 (markers of autophagy), Bcl-2, and AR were detected by immunofluorescence, whereas caspase-3 (marker of apoptosis) and connexin-43 were detected by immunohistochemistry. Non-serial paraffin sections were immersed in $0.001 \mathrm{M}$ citrate buffer $\mathrm{pH} 6.0$ and heated in a microwave oven at $90^{\circ} \mathrm{C}$ during $30 \mathrm{~min}$ for antigen recovery. For the immunohistochemistry reaction, the endogenous peroxidase was inactivated with hydrogen peroxide. The sections were incubated with BSA $2 \%$ for 30 min to block non-specific binding. After washes in PBS, the sections were incubated in a humified chamber at $4^{\circ} \mathrm{C}$ overnight with the following primary antibodies: mouse antiPGP9.5 (Protein Gene Product) MAB (1:800; Biocare Medical, Concord, USA; CM 329 AK), mouse anti-p62/SQSTM1 MAB (1:100; Santa Cruz; sc-28359), mouse anti-Bcl-2 MAB (1:200; Santa Cruz; sc-7382), rabbit anti-MAP LC3A polyclonal antibody (1:90; Santa Cruz; sc-134226), rabbit anti-AR polyclonal antibody (1:150; Millipore; 06-680 PG-21), and rabbit anti-active caspase-3 antibody (1:100; Abcam). The sections submitted to immunofluorescence reactions were washed in PBS and incubated at room temperature in darkness for $1 \mathrm{~h}$ with appropriate secondary antibodies. Detection of PGP9.5, p62/SQSTM1, and Bcl-2 was performed using Alexa Fluor 488 anti-mouse antibody (1:1000; Life Technologies), whereas MAP LC3A and AR were detected by Alexa Fluor 594 
anti-rabbit antibody ReadyProbes ${ }^{\circledR}$ reagent (Life Technologies; R37117). After washes in PBS, nuclear staining was performed with DAPI (Life Technologies) for $5 \mathrm{~min}$ in darkness at room temperature and the slides were mounted with Fluoromount G mounting medium (EMS, Hatfield, USA). For detection of active caspase- 3 by immunohistochemistry, the sections were washed in PBS and incubated with Labelled StreptAvidin-Biotin Kit (Universal Dako LSAB, Dako Inc.) at room temperature. The reaction was revealed with 3,3'-diaminobenzidine (DAB, Sigma-Aldrich) and the sections were counterstained with haematoxylin.

The protocol for immunolocalization of connexin-43 was performed according to Hermo et al. (2007) and Oliveira et al. (2016), with some modifications. The sections were treated with $0.3 \mathrm{M}$ glycine for $5 \mathrm{~min}$ and washed in PBS. Antigen recovery was performed in a microwave oven at $90^{\circ} \mathrm{C}(3 \times 15$ min) using $0.1 \mathrm{M}$ citrate buffer $\mathrm{pH}$ 6.0. After inactivation of endogenous peroxidase with hydrogen peroxide, the sections were washed in PBS for $10 \mathrm{~min}$ and incubated at $37^{\circ} \mathrm{C}$ for 2 h with the mouse anti connexin-43 MAB (1:30; Santa Cruz; sc-271837). The sections were washed in PBS, incubated for $1 \mathrm{~h}$ at room temperature with the Dako Envision Dual Link System-HRP (Dako Inc., Carpinteria; K4061). The reactions were reveled with $\mathrm{DAB}$, and the sections were counterstained with haematoxylin.

For all markers evaluated, negative controls were performed by incubating the sections with non-immune serum in place of primary antibodies.

\section{UCHL1, MAP LC3A, and p62/SQSTM1 immunofluorescent areas}

Immunofluorescent areas were analyzed using DFC 550 Camera (Leica) attached to a BM4000 B LED microscope (Leica) and the Leica Application Suite software (LAS 4.3, Leica).

In four non-serial sections per animal, the immunofluorescent area of UCHL1, MAP LC3A, and p62/SQSTM1 was measured in proximal cauda epididymis. The immunolabeled areas were measured in a total standardized epithelial area of 50,000 $\mu \mathrm{m}^{2}$ per animal and the immunofluorescent area per square micrometre was obtained.

All parameters of the software Leica Application Suite (LAS 4.3, Leica), including threshold adjustment and color range (hue, saturation, and intensity), were rigorously standardized in all sections for the analyzes of immunofluorescent areas.

\section{Western blot}

The protocol was performed according to de Santi et al. (2018). Frozen cauda epididymis fragments were homogenized in lysis buffer for protein extraction, and protein samples (30 $\mu \mathrm{g}$ for UCHL1 or Bcl-2 and $45 \mu \mathrm{g}$ for $\mathrm{Cx} 43)$ were separated in SDS-PAGE (15\% for UCHL-1 or Bcl-2 and $10 \%$ for Cx43) and transferred to nitrocellulose membrane (GE Healthcare). The membranes were incubated overnight at $4{ }^{\circ} \mathrm{C}$ with mouse anti-PGP9.5 (Protein Gene Product) MAB (1:1000; Biocare Medical, Concord, USA; CM 329 AK), mouse anti-Bcl-2 MAB
(1:200; Santa Cruz; sc-7382), and mouse anti-Cx43 MAB (1:500; Santa Cruz; sc-271837). After washes in PBS/T, the membranes were incubated for $1 \mathrm{~h}$ at room temperature with HRP-conjugated anti-mouse secondary antibody (1:2000; Sigma-Aldrich). The membranes were washed in PBS/T and the reactions were detected using ECL Plus Western Blotting Substrate (Boster Biological Technology, Pleasanton, USA; AR1196). For positive controls, the membranes were stripped and incubated with rabbit anti- $\beta$-tubulin MAB (1:1000; Abcam; ab108342) and HRP-conjugated anti-rabbit secondary antibody (1:7500; Sigma-Aldrich). The assays were reproduced in triplicate for CG and CMTG.

\section{Real time polymerase chain reaction (qPCR)}

The expression of the androgen-responsive genes Crisp1 (Haendler et al. 1997, Roberts et al. 2001) and Connexin43 (Cx43) (Lydka et al. 2011, Firestone \& Kapadia 2012) was evaluated by qPCR. RNA was extracted from cauda epididymis samples using Aurum Total RNA Mini Kit (Bio-Rad Laboratories; 732-6820), and RT was performed using HighCapacity cDNA RT Kit (Applied Biosystems; 4368814). For qPCR, PowerUp SYBR Green Master Mix (Applied Biosystems; A25742) and the QuantStudio 3 Real-Time PCR instrument (Applied Biosystems) were used. Standard curves at each individual run were used for all genes analyzed, and gene expression was presented as ratio to the housekeeping control. All primers were designed using the murine sequence available at the University of California, Santa Cruz (UCSC), Genome Browser and the Primer3 program (Koressaar \& Remm 2007, Untergasser et al. 2012) (Table 1).

\section{Statistical analysis}

The data were checked for normal distribution by the D'Agostino-Pearson normality test and analyzed by Student's $t$-test at a significance level of $P<0.05$ using GraphPad Prism 6.01 software.

\section{Results \\ Cimetidine-induced androgenic failure in cauda epididymis}

Either the relative weight of seminal vesicles or the expression of the androgen-responsive genes Crisp 1 and Cx43 reduced significantly in CMTG (Figs $1 \mathrm{~A}, \mathrm{~B}$ and $5 \mathrm{H}$ ).

Table 1 Sequence of primers used in qPCR reactions.

\begin{tabular}{ll}
\hline Gene & Sequence $\left(5^{\prime}-3^{\prime}\right)$ \\
\hline Crisp1 & CCTCATTGGCTGTGATGTTG \\
& CGTAATAAAGGCAGGGGTTG \\
C 433 & AGCAAGCTAGCGAGCAAAAC \\
& GAGTTCATGTCCAGCAGCAA \\
$\beta$-Actin & ACGGTCAGGTCATCACTATC \\
& TGCCACAGGATTCCATACC \\
\hline
\end{tabular}



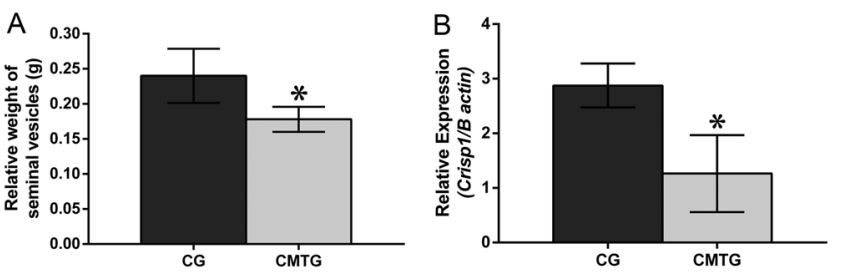

Figure 1 The relative weight of seminal vesicles (A) and the expression of the androgen-responsive gene Crisp 1 (B) reduced significantly in CMTG $\left({ }^{*} P=0.0117(\mathrm{~A}) ;{ }^{*} P=0.0262(\mathrm{~B})\right)$.

\section{Androgenic failure on the muscular layer}

In CG, an evident smooth muscular layer was observed surrounding the epithelium on one side (Fig. 2A and C) and interconnected with the connective tissue on the opposite side (Fig. 2A). However, in CMTG, either the muscular layer or the epithelium was thinner than in CG (Fig. 2A, B, C and D) and scarce portions of connective tissue interconnected with the muscular layer were observed (Fig. 2B). The morphometric analyses

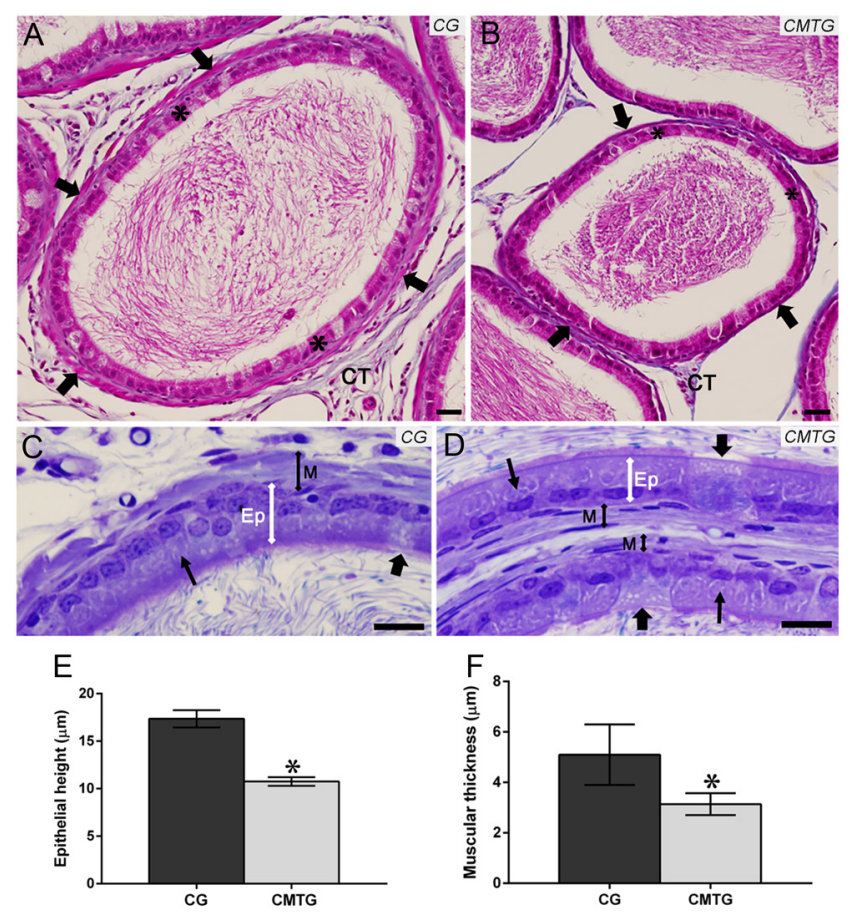

Figure 2 Photomicrographs of proximal cauda epididymis region sections of animals from CG $(A, C)$ and $C M T G(B, D)$. In A and B, epididymal sections stained with Masson's trichrome show muscular layer (arrows) surrounding the epithelium (asterisks) and interconnected with the connective tissue (CT). In B, note the scarce connective tissue (CT); the muscular layer (arrows) and the epithelium (asterisks) are thinner than in A. In C and D, epididymal sections stained with toluidine blue show principal (thin arrows) and clear (thick arrows) cells in the epithelium. In D, note the thin muscular layer $(M)$ and reduced epithelial height $(E p)$. Bars $=36 \mu \mathrm{m}$ $(\mathrm{A}, \mathrm{B}) ; 18 \mu \mathrm{m}(\mathrm{C}, \mathrm{D})$. The epithelial height (E) and the muscular thickness (F) of animals from CMTG are significantly reduced in comparison with CG $\left({ }^{*} P=0.002(\mathrm{E}) ;{ }^{*} P=0.0089(\mathrm{~F})\right)$. confirmed the significant reduction in the epithelial height and in the muscular thickness of animals from CMTG (Fig. 2E and F). In CMTG, several smooth muscle cells positive to the TUNEL method or immunolabeled to active caspase-3 were found (Fig. 3B, C, E and F), whereas scarce labeled cells were seen in CG (Fig. $3 \mathrm{~A}$ and $\mathrm{D})$. In the sections used as negative controls, no immunolabeling or TUNEL positivity was observed (Fig. 3G and H). The number of TUNEL-positive smooth muscle cells increased significantly in CMTG (Fig. 3I).

Under TEM, superimposed layers of fusiform shapedsmooth muscle cells with elliptical and regularly outlined nuclei were normally in close contact to each other by adherens junctions in CG (Fig. 4A and C). Otherwise, in CMTG, the muscle cells showed convoluted surface and were detached from each other. The large spaces between these cells were filled with

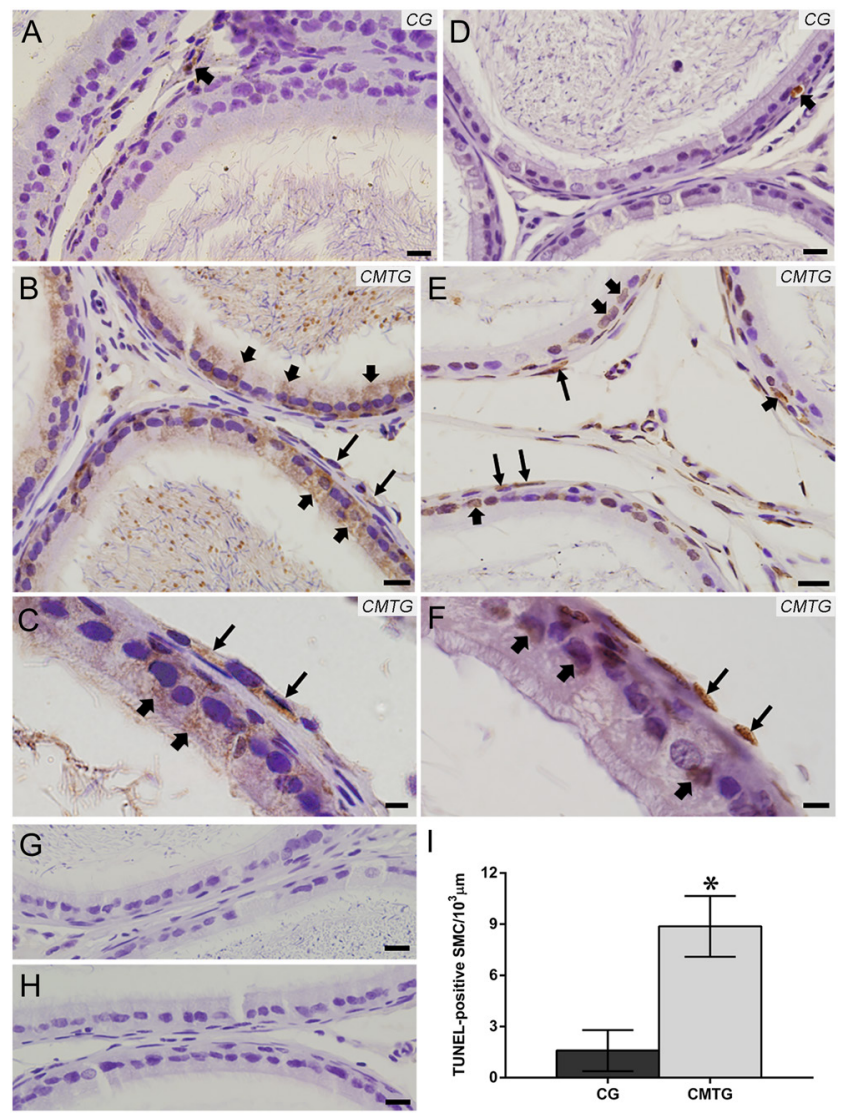

Figure 3 Photomicrographs of proximal cauda epididymidis region sections of animals from CG and CMTG subjected to caspase-3 immunohistochemistry (A, B, C) and TUNEL method (D, E, F). In A and $\mathrm{D}$, scarce immunolabeled cells are observed in CG (arrows). In B and $\mathrm{C}$, epithelial (thick arrows) and smooth muscle cells (thin arrows) are positive to caspase- 3 immunohistochemistry. In E and F, TUNEL-positivity is observed in epithelial (thick arrows) and smooth muscle cells (thin arrows). $\mathrm{G}$ and $\mathrm{H}$ show negative controls of caspase-3 (G) and TUNEL (H). Bars $=18 \mu \mathrm{m}(\mathrm{A}, \mathrm{B}, \mathrm{D}, \mathrm{E}, \mathrm{G}, \mathrm{H}) ; 7 \mu \mathrm{m}$ (C, F). (I) In CMTG, the number of TUNEL-positive smooth muscle cells is significantly higher than in CG $(* P<0.0001)$. 


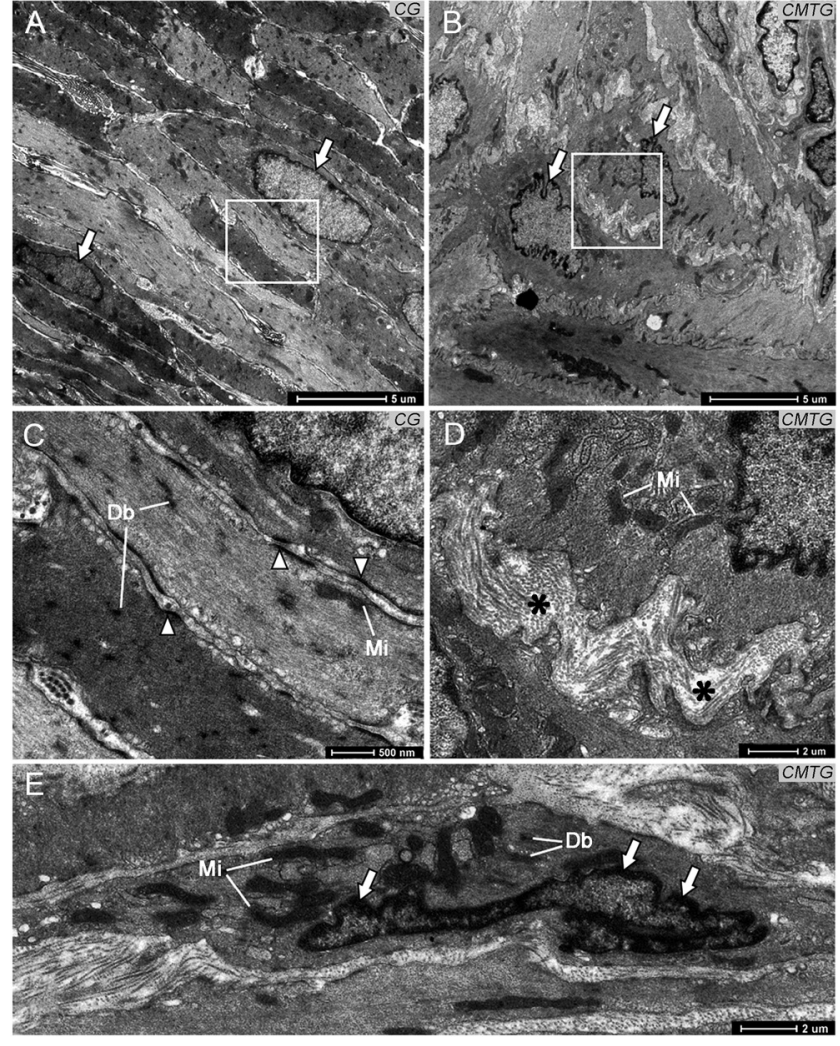

Figure 4 Electron micrographs of portions of smooth muscular layer surrounding the epididymal epithelium in CG (A and C) and CMTG (B, D, E). In A, superimposed layers of fusiform smooth muscle cells with elliptical and regularly outlined nuclei (arrows). In a portion of these cells under high magnification $(\mathrm{C})$, note the close contact between the cells, which are attached by adherens junctions - dense plaques (arrowheads). In B, the smooth muscle cells surface are intensely convoluted and the round/ovoid nuclei irregularly outlined show electron dense chromatin in the periphery (arrows). Under high magnification (D), note that the cells are detached from each other and a large space filled with collagen fibrils (asterisks) are observed between them. In E, a damaged smooth muscle cell shows convoluted nucleus with masses of condensed chromatin in the periphery (arrows). Dense bodies (Db); Mitochondria (Mi).

collagen fibrils (Fig. 4B and D). Moreover, the round/ ovoid or convoluted nuclei were irregularly outlined and showed masses of condensed chromatin in the nuclear periphery, typical of apoptosis (Fig. 4B and E).

In CG, a punctual and sparse Cx43 immunolabeling was detected in the smooth muscle cells of epididymal cauda (Fig. 5A and B). Moreover, either in CG or CMTG, Cx43 immunostaining in epithelial cells (probably basal cells) was often seen. However, a weak or no immunoexpression was noted in the thin muscular layer of CMTG (Fig. 5C, D and E). In epididymal cauda extracts of CMTG, low levels of Cx43 were detected by Western blot (Fig. 5G). The gene expression of $\mathrm{Cx} 43$ was also significantly lower in CMTG than in CG (Fig. 5H).

In the sections of cauda epididymis of animals from CG, an evident AR immunofluorescence was observed

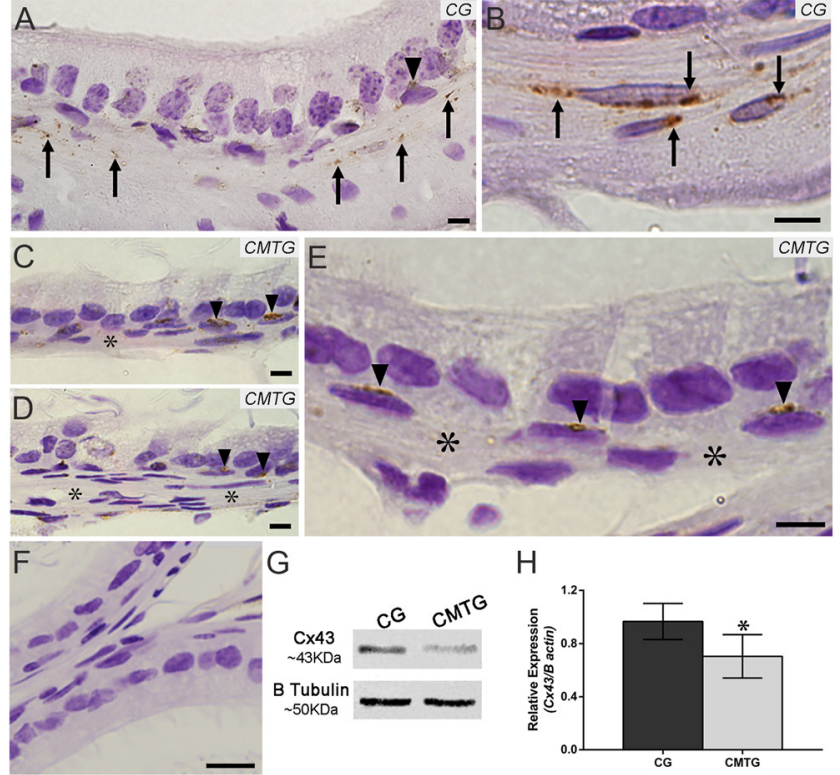

Figure 5 Photomicrographs of proximal cauda epididymidis region sections subjected to immunohistochemistry for detection of $\mathrm{Cx} 43$ and nuclear staining with haematoxylin. In A and B, a punctual and sparse immunostaining is observed in smooth muscle cells (arrows). whereas in $\mathrm{C}, \mathrm{D}$ and $\mathrm{E}$, no immunolabeling is noted in the thin muscular layer (asterisks). Either in CG (A) or CMTG (C, D, E), epithelial cells (probably basal cells) are also immunolabeled (arrowheads). (F) Negative control. Bars $=7 \mu \mathrm{m}$ (A, C, D, E); 18 $\mu \mathrm{m}$ (B, F). (G) Western blot analysis of Cx43 in cauda extracts. A weak band at $43 \mathrm{kDa}$ (Cx43 molecular weight) is observed in CMTG. Tubulin signal is observed in both groups. (H) $\mathrm{Cx} 43$ expression reduced significantly in CMTG $* P=0.0484$.
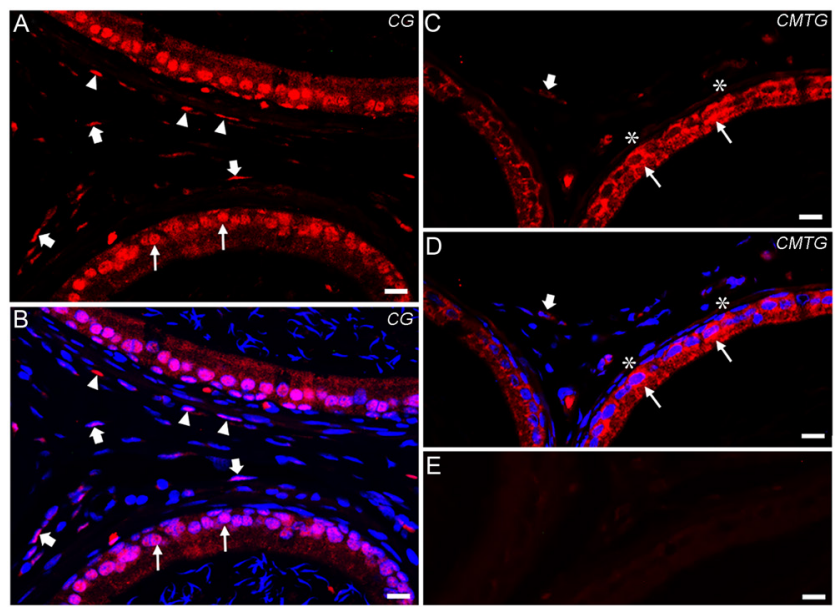

Figures 6 Photomicrographs of proximal cauda epididymidis region sections subjected to immunofluorescence for detection of AR and nuclear staining with DAPI (overlay, B and D). Evident AR immunofluorescence is observed in the nuclei of epithelial cells (thin arrows), fibroblasts (thick arrows), and smooth muscle cells (arrowheads) in CG (A, B). In CMTG, a diffuse immunoreaction is observed in the epithelial cells cytoplasm (thin arrows) and a weak or no AR immunolabeling is observed in the nuclei of fibroblasts (thick arrow) and smooth muscle cells (asterisks) (C, D). E, negative control. Bars $=18 \mu \mathrm{m}$. 
in the nuclei of epithelial cells, smooth muscle cells, and fibroblasts (Fig. 6A and B). However, in CMTG, the epithelial cells showed a diffuse AR immunoexpression in the cytoplasm, and the scarce fibroblasts and smooth muscle cells were weakly immunolabeled (Fig. 6C and D). In both reactions for detection of $\mathrm{Cx} 43$ or $\mathrm{AR}$, no immunolabeling was detected in the negative controls (Figs $5 \mathrm{~F}$ and $6 \mathrm{E}$ ).

\section{Immunoexpression of BCl-2, UCHL1, and autophagy in the epithelial cells}

The immunofluorescence for detection of PGP9.5 (UCHL1) in the epithelial cells showed a strong immunofluorescence in CMTG (Fig. 7C and D) when compared to CG (Fig. 7A and B). The quantitative analysis showed a significant increase in the PGP9.5 (UCHL1) immunofluorescent area per square micrometre of epididymal epithelium in CMTG (Fig. 7F). Moreover, these results were confirmed by the high levels of this protein detected by Western blot in CMTG (Fig. 7G).

A slight immunoexpression of the autophagic markers MAP LC3A (Fig. 8A and B) and p62/SQSTM1 (Fig. 8E and $F$ ) was observed in the epididymal epithelial cells of animals from CG, whereas an intense immunoexpression of these markers was detected in CMTG (Fig. 8C, D, $\mathrm{G}$ and $\mathrm{H})$. The quantitative analyses confirmed the significant increase in the immunofluorescent area of both markers in CMTG (Fig. 8K and L).

A weak immunoexpression of $\mathrm{BCl}-2$ was detected in the epididymal epithelial cells of CMTG in contrast to a strong immunolabeling in CG (Fig. 9A, B, C and D). These results were in agreement with the low levels of this anti-apoptotic factor observed in the epididymal cauda extracts of CMTG in contrast to the high levels in CG (Fig. 9F).

In all sections used as negative controls for each antigen, no immunofluorescence was detected (Figs 7E, $8 \mathrm{I}, \mathrm{J}$ and $9 \mathrm{E})$.

\section{Discussion}

In cauda epididymis, cimetidine reduces sex hormonebidding globulin (SHBG) levels in the stromal tissue and impairs AR nuclear import in epithelial cells, leading to apoptosis in the epithelial cells and reduction in the epididymal duct diameter (de Santi et al. 2018). Thus, we investigated the integrity of proximal cauda epididymis muscular layer as well as the immunoexpression of UCHL1 (a component of UPS) and autophagic markers in the epithelium of the androgen-deficient epididymis induced by cimetidine. In the present study, besides a diffuse cytoplasmic AR immunolabeling in the epithelial cells, confirming failure in AR nuclear import, the reduction of seminal vesicle weight and downregulation of the androgen-responsive genes Crisp 1 and Cx43
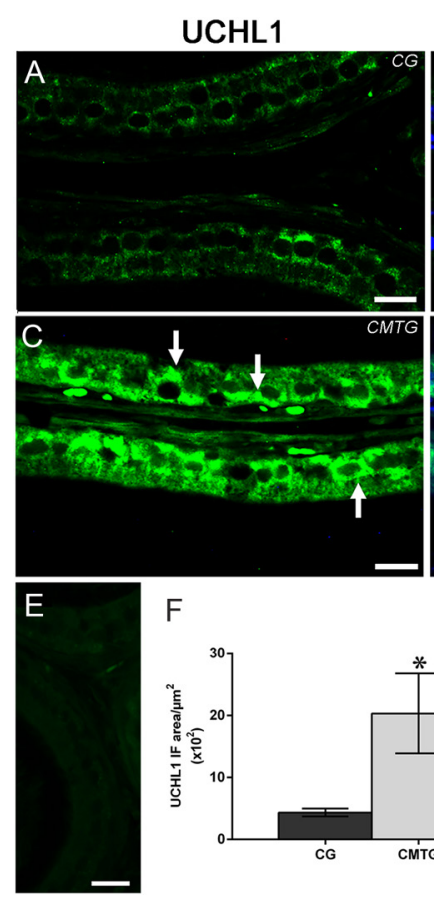

$\mathrm{F}$

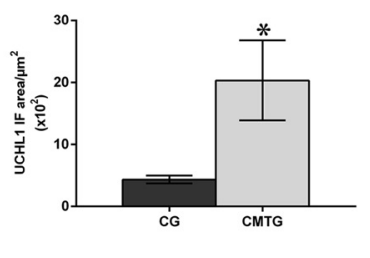

\section{OVERLAY}

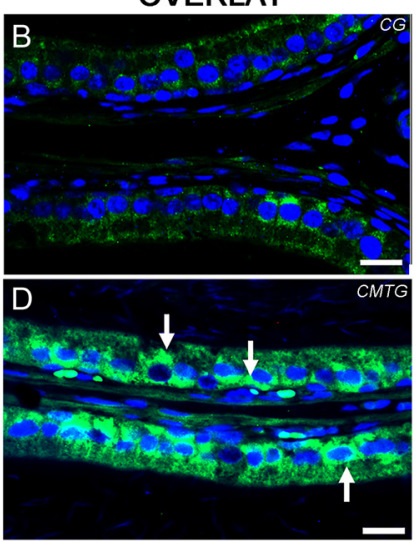

G

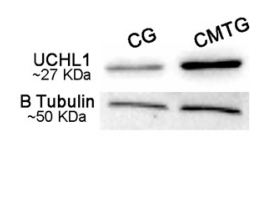

Figures 7 Photomicrographs of proximal cauda epididymis region sections of animals from CG (A and B) and CMTG $(C$ and $D)$ showing immunofluorescence of PGP9.5 (UCHL1) and nuclear staining with DAPI. Note the enhanced UCHL1 immunolabeling (arrows) in CMTG when compared to CG. E, negative control. Bars $=18 \mu \mathrm{m}$. (F) The UCHL1 immunofluorescent area per square micrometre of epididymal epithelium increased significantly in CMTG $\left({ }^{*} P=0.0006\right)$. (G) Western blot analysis of PGP9.5 (UCHL1) levels in cauda extracts. A band at $27 \mathrm{kDa}$, corresponding to the PGP9.5 molecular weight, is stronger in CMTG than in CG. Tubulin signal is observed in both groups.

supported the androgenic dysfunction in CMTG. Moreover, the significant decrease in $\mathrm{Cx} 43$ was consonant with the presence of muscle cells apoptosis and reduction in the muscular layer thickness. These findings, in association with the weak immunoexpression of Cx43 and AR in the smooth muscle cells, confirm the importance of androgens for these cells. The presence of cell death in the epithelium, the low immunoexpression of $\mathrm{BCl}-2$, and reduction in the epithelium height were correlated with increased UCHL1 immunoexpression, indicating that this deubiquitinating enzyme (DUB) plays a role in the epididymal epithelial cells death under androgen deficiency. The intense immunoexpression of MAP LC3A and p62/SQSTM1 in CMTG indicates impaired autophagy and points to a correlation between UCHL1 and autophagy in the regulation of epididymal epithelial cells apoptosis under androgen regulation.

\section{Androgenic failure on epididymal smooth muscle cells}

We have demonstrated that cimetidine treatment reduces serum testosterone levels (Beltrame et al. 2015, 2019, 

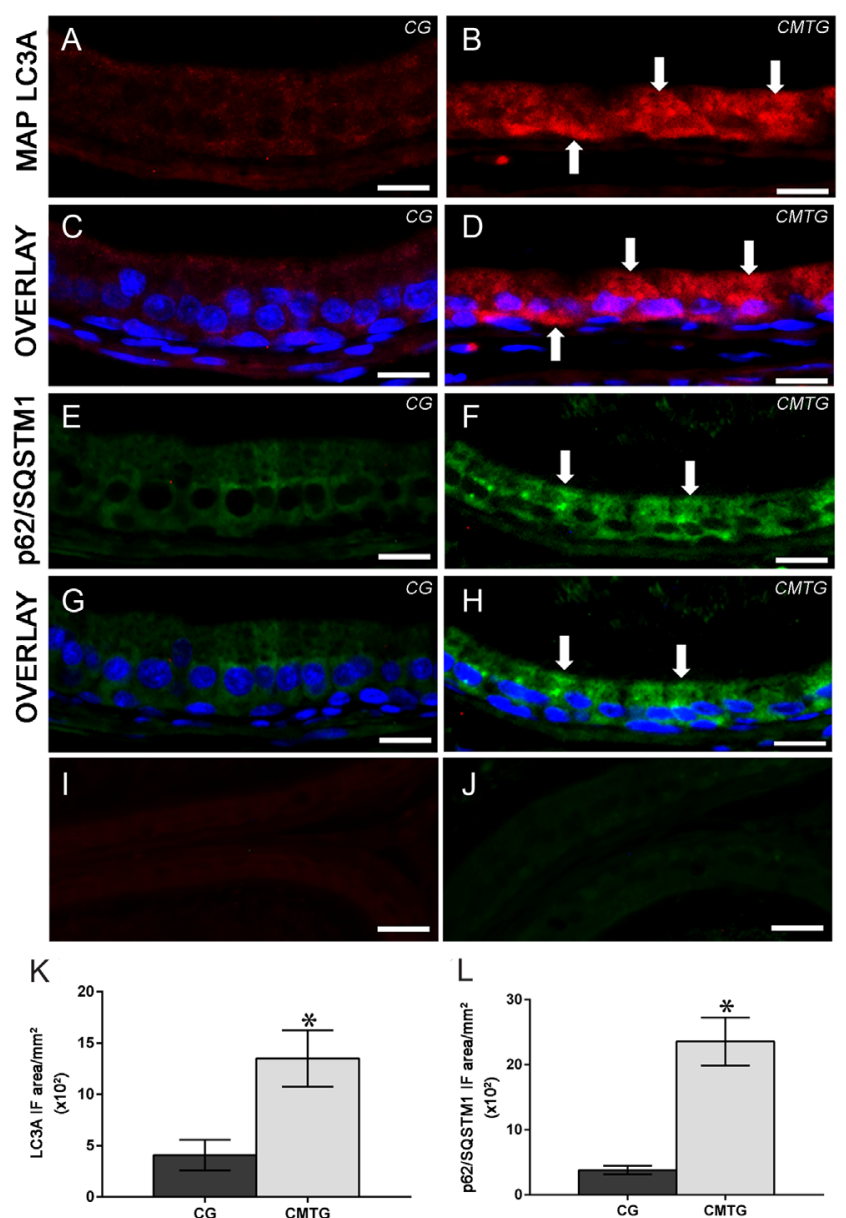

Figures 8 Photomicrographs of proximal cauda epididymis region sections showing MAP LC3A (A, B, C, D) and p62/SQSTM1 (E, F, G, $\mathrm{H})$ immunofluorescence and nuclear staining with DAPI. Note the enhanced immunofluorescence for both markers in the epithelium of CMTG (arrows; C, D, G and $\mathrm{H}$ ) in comparison to CG (A, B, E and F). (I and J) Negative controls. Bars $=18 \mu \mathrm{m}$. (K and L) Either LC3A (K) or p62/SQSTM1 (L) immunofluorescence area per square micrometre of epididymal epithelium is significantly increased in CMTG.

$\left({ }^{*} P=0.0001(\mathrm{~K}) ;{ }^{*} P<0.0001(\mathrm{~L})\right)$.

de Santi et al. 2018) in association with changes in Leydig cells (Beltrame et al. 2015) and in the seminiferous epithelium (Sasso-Cerri \& Miraglia 2002, Sasso-Cerri \& Cerri 2008, Beltrame et al. 2011, 2019, Beltrame \& Sasso-Cerri 2016). Here, the reduction in seminal vesicles weight in association with downregulation of the androgen-responsive genes Crisp1 (Haendler et al. 1997, Roberts et al. 2001) and Cx43 (Lydka et al. 2011, Firestone \& Kapadia 2012) confirms the androgen dysfunction induced by cimetidine in cauda epididymis, in which blockade of epithelial AR nuclear import and low SHBG stromal levels have been previously demonstrated (de Santi et al. 2018). In the present study, a weak AR immunofluorescence was also detected in the epididymal smooth muscle cells of CMTG. This result is in agreement with the low AR levels in the total

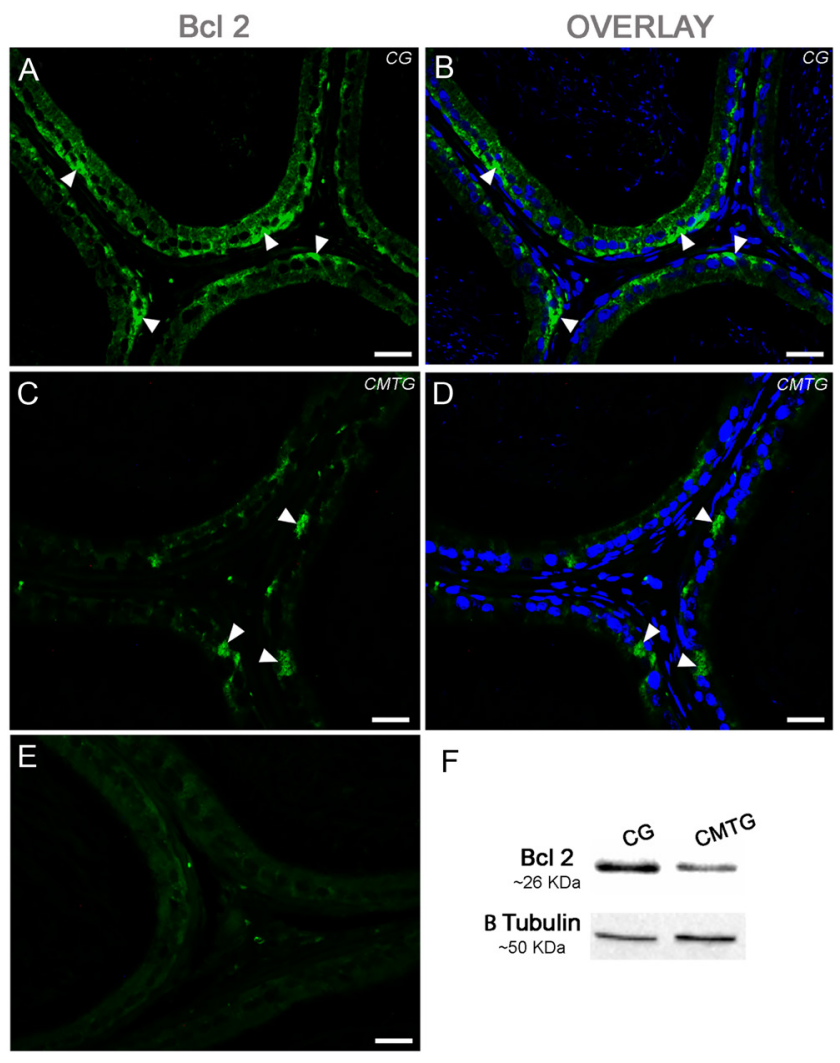

Figures 9 Photomicrographs of proximal cauda epididymis region sections showing $\mathrm{BCl}-2$ immunofluorescence and nuclear staining with DAPI in CG (A and B) and CMTG (C and D). In CG (A and B), an evident immunelabeling is noted in the basal portion of cells throughout the epithelium (arrowheads), whereas in CMTG (C and D), few cells show immunofluorescence (arrowheads). E: negative control. Bars $=18 \mu \mathrm{m}$. (F) Western blot analysis of Bcl-2 levels in cauda extracts. A band at $26 \mathrm{kDa}$, corresponding to the $\mathrm{Bcl}-2$ molecular weight, is stronger in CG than in CMTG. Tubulin signal is observed in both groups.

epididymal extract (de Santi et al. 2018) and is also consonant with the low expression of both $\mathrm{Cx} 43$ and Crisp1 demonstrated in the present study.

Cx43 is present in GAP junctions between smooth muscle cells, including in muscular layer of cauda epididymis (Cyr et al. 1996, Oliveira et al. 2016). Studies indicated that GAP junctions may transmit survival signals or inhibit death signals by limiting the flux of toxic molecules (Vinken et al. 2006, Du et al. 2017). Blockage of testicular connexins induces germ cell death (Lee et al. 2006), and the reduction in Cx43 levels were associated with increased apoptosis in osteocytes (Davis et al. 2017), vascular smooth muscle cells (Tang \& Fang 2017), and cardiomyocytes (Du et al. 2017). The animals from CMTG showed a high incidence of TUNEL-positive and caspase-3-immunolabeled muscle cells in cauda epididymis. Moreover, apoptotic ultrastructural features and loss of contact between muscle cells were also observed. These findings 
associated with weak immunoexpression of $\mathrm{Cx} 43$ in the muscular layer confirm that these cells undergo apoptosis, at least in part, due to downregulation of Cx43 induced by androgenic dysfunction. Besides Cx43, apoptosis is also activated by excessive elevation of intracellular $\mathrm{Ca}^{+2}$ levels (Kondratskyi et al. 2015). Androgens can regulate intracellular $\mathrm{Ca}^{+2}$ levels due to the direct inhibition of type $\mathrm{L} \mathrm{Ca}^{+2}$ channels (Scragg et al. 2004, 2007). In epididymis, androgen deprivation may increase the levels of $\mathrm{Ca}^{+2}$ due to the inhibition of phosphodiesterase (Holtz et al. 1981). Therefore, the reduction in androgen bioavailability in CMTG may disturb $\mathrm{Ca}^{+2}$ homeostasis, inducing smooth muscle cells apoptosis, as also suggested in muscle cells of testicular blood vessels (Beltrame et al. 2012) and vas deferens (Koshimizu et al. 2013). Further studies are necessary to clarify the mechanism by which smooth muscle cells undergo apoptosis under androgenic deficiency in epididymis.

Our findings are in accordance with previous studies, which demonstrated the susceptibility of smooth muscle cells to cimetidine treatment (França et al. 2000, SassoCerri \& Miraglia 2002, Beltrame et al. 2012, Koshimizu et al. 2013). Since in cauda epididymis androgen supply is probably provided by the blood stream, the low immunoexpression of AR either in smooth muscle cells or in stromal fibroblasts may impair drastically the androgen supply to cauda epididymis.

\section{UCHL1 and autophagy in the epididymal epithelial cells under androgenic dysfunction}

The role of UCHL1 in the male reproductive system has not yet been fully understood. In fluoxetine-treated rats, this antidepressant reduces testosterone synthesis and increases the immunoexpression of UCHL1 in the seminiferous epithelium, indicating that androgens may regulate this hydrolase (Câmara et al. 2019). Here, the high levels of UCHL1 observed in the androgendeficient epididymal epithelium support this hypothesis. The epididymal epithelium secretes UCHL1 Baska et al. 2008) and other components of the ubiquitinproteasome system (UPS) (Sutovsky et al. 2001, Baska et al. 2008), which were associated with the extracellular ubiquitination of defective spermatozoa in the luminal fluid (Sutovsky 2003, Eskandari-Shahraki et al. 2013). However, UCHL1 deficient mice caput epididymal epithelial cells, which normally undergo apoptosis under androgenic failure induced by efferent duct ligation, were resistant to cell death (Kwon et al. 2006). In rodent testes, UCHL1 probably controls the balance between pro-apoptotic and anti-apoptotic factors (Wang et al. 2006, Kwon 2007) and high levels of this enzyme have been directly proportional to the incidence of germ cells death (Kwon et al. 2004b, 2006, Câmara et al. 2019). Ectopically expressed UCHL1 in tumour cells reduces the levels of anti-apoptotic proteins, such as Bcl-2 (Wang et al. 2008), and stabilizes the pro-apoptotic factor p53 due to its deubiquitination (Li et al. 2010). Moreover, mice lacking UCHL1 present high levels of the anti-apoptotic proteins $\mathrm{Bcl}-2$ and $\mathrm{Bcl}-\mathrm{xL}$ in the caput epididymis (Kwon et al. 2006). Therefore, the high incidence of apoptosis in the epididymal epithelial cells of cimetidine-treated rats (de Santi et al. 2018) may be associated with possible degradation of anti-apoptotic factors induced by increased UCHL1. The low Bcl-2 levels observed here support this idea and these results point to a role of this enzyme in the regulation of cell death in epididymis.

Besides apoptosis, UPS also seems to interact with the autophagic pathway (Ding et al. 2007), an essential process for the elimination of protein aggregates and damaged organelles, maintaining cell viability (Doherty \& Baehrecke 2018). The autophagosome formation depends on MAP LC3A, and the levels of this protein have been used as autophagy marker (Klionsky et al. 2016). However, since autophagosome is a transient structure, LC3 levels alone do not reflect the autophagic flux (Klionsky et al. 2016). On the other hand, the autophagic receptor p62/SQSTM binds to ubiquitinated cargos, delivering them to the autophagosome (Kaur \& Debnath 2015), being degraded during autophagy. Thus, when autophagy is disrupted, high levels of p62/ SQSTM1 are found in cells (Klionsky et al. 2016). In the present study, the intense MAP LC3A and p62/SQSTM1 immunofluorescence indicates a reduction or blockage of the autophagic flux following cimetidine-induced androgenic failure. Inhibition of autophagy, evidenced by increase in these autophagic markers, has also been observed in Leydig cells of rats (Li etal. 2011) and humans (Gao et al. 2018) under reduced serum testosterone levels, as well as in osteocytes of ovariectomized rats (Florencio-Silva et al. 2018). Otherwise, androgens promote prostate cancer cell growth in vitro, at least in part, due to induction of autophagy (Shi et al. 2013, Blessing et al. 2017). Therefore, our findings reinforce the idea that autophagy is an androgen-dependent process.

When the intensity of a stressor overcomes the cytoprotective function of autophagy, the apoptotic pathway is activated (Mariño et al. 2014). During this process, proteins involved in autophagy are degraded, shutting down the autophagic process and amplifying the apoptotic response (Mariño et al. 2014, Ouyang et al. 2014). Inhibition of autophagy by siRNA, pharmacological inhibitors, or steroid deprivation results in increased apoptosis (He et al. 2012, Park et al. 2013, Florencio-Silva et al. 2018). Here, we demonstrated a correlation between epithelial cells apoptosis and increased UCHL1 in parallel to an interference in autophagy under androgen deprivation. Therefore, UCHL1 and autophagy are probably 
involved in the maintenance of cauda epididymis epithelial cells viability. The pharmacological inhibition of UCHL1 enhances protein degradation by autophagic pathway (Cartier et al. 2012, Zhang et al. 2014, Pukaß \& Richter-Landsberg 2015), whereas the overexpression of this enzyme suppresses autophagy (Zhang et al. 2014, Yan et al. 2018). This finding is confirmed by the fact that UCHL1 interacts with MAP LC3A to block autophagosome formation in HeLa cells (Yan et al. 2018). Therefore, the impairment in autophagy observed in the epididymal epithelial cells under androgenic failure may be associated with the increased UCHL1 immunoexpression. According to our knowledge, this is the first study suggesting an interplay among UCHL1, autophagy, and apoptosis in epididymal epithelial cells under androgenic control.

In conclusion, cimetidine-induced androgenic failure impairs the muscular layer of cauda epididymis, reducing Cx43, causing loss of adhesion between smooth muscle cells and inducing apoptosis. These data highlight the importance of stromal androgenic supply for the maintenance of smooth muscle cells viability in cauda epididymis. The reduction of epithelial high induced by androgenic failure may be associated with the reduction in Bcl-2 levels and epithelial cells apoptosis. This finding agrees with the increased levels of UCHL1 in the epithelium and points to a role of this deubiquitinating enzyme in the apoptotic pathway under androgenic control. Cimetidine-induced androgen deprivation also inhibited the autophagy, which in association with the increased UCHL1 levels reinforces a possible role of ubiquitin-proteasome system in the autophagic control. Therefore, our results suggest an interplay between UCHL1 and autophagy in the regulation of apoptosis in epididymal epithelium and that androgens seem to orchestrate these processes.

\section{Declaration of interest}

The authors declare that there is no conflict of interest that could be perceived as prejudicing the impartiality of the research reported.

\section{Funding}

This research was supported by FAPESP (2012/23845-3; 2015/09341-0; 2015/12501-0; 2017/19829-6).

\section{Author contribution statement}

F de Santi, F L Beltrame, and E Sasso-Cerri conceptualized the research. F de Santi, P S Cerri, and E Sasso-Cerri performed data curation. P S Cerri performed formal analysis. E SassoCerri acquired funding. F de Santi, I D Lunardi, F L Beltrame, P $S$ Cerri, and E Sasso-Cerri performed laboratory investigations.
F de Santi, I D Lunardi, F L Beltrame, and P S Cerri devised the methodology. E Sasso-Cerri supervised the study. F L Beltrame, P S Cerri, and E Sasso-Cerri performed validatory analysis. F de Santi visualized the study. F de Santi, I D Lunardi, F L Beltrame, and E Sasso-Cerri wrote the original draft. F de Santi, P S Cerri, and $\mathrm{E}$ Sasso-Cerri reviewed and edited the final version of the manuscript.

\section{Acknowledgements}

The authors thank Luis Antônio Potenza and Pedro Sérgio Simões for the histological technical assistance. The authors also thank Dr Flávia L Lopes for the primers design.

\section{References}

Amerik AY \& Hochstrasser M 2004 Mechanism and function of deubiquitinating enzymes. Biochimica et Biophysica Acta 1695 189-207. (https://doi.org/10.1016/j.bbamcr.2004.10.003)

Baska KM, Manandhar G, Feng D, Agca Y, Tengowski MW, Sutovsky M, Yi YJ \& Sutovsky P 2008 Mechanism of extracellular ubiquitination in the mammalian epididymis. Journal of Cellular Physiology 215 684-696. (https://doi.org/10.1002/jcp.21349)

Beltrame FL \& Sasso-Cerri E 2016 Vitamin $B_{12}$-induced spermatogenesis recovery in cimetidine-treated rats: effect on the spermatogonia number and sperm concentration. Asian Journal of Andrology 18 1-6. (https:// doi.org/10.4103/1008-682X.182397)

Beltrame FL, Caneguim BH, Miraglia SM, Cerri PS \& Sasso-Cerri E 2011 Vitamin $B_{12}$ supplement exerts a beneficial effect on the seminiferous epithelium of cimetidine-treated rats. Cells, Tissues, Organs 193 184-194. (https://doi.org/10.1159/000319371)

Beltrame FL, Yamauti CT, Caneguim BH, Cerri PS, Miraglia SM \& SassoCerri E 2012 Cimetidine-induced vascular cell apoptosis impairs testicular microvasculature in adult rats. Histology and Histopathology 27 1343-1351. (https://doi.org/10.14670/HH-27.1343)

Beltrame FL, Cerri PS \& Sasso-Cerri E 2015 Cimetidine-induced Leydig cell apoptosis and reduced EG-VEGF (PK-1) immunoexpression in rats: evidence for the testicular vasculature atrophy. Reproductive Toxicology 57 50-58. (https://doi.org/10.1016/j.reprotox.2015.05.009)

Beltrame FL, de Santi F, Vendramini V, Cabral REL, Miraglia SM, Cerri PS \& Sasso-Cerri E 2019 Vitamin $B_{12}$ prevents cimetidine-induced androgenic failure and damage to sperm quality in rats. Frontiers in Endocrinology 10 309. (https://doi.org/10.3389/fendo.2019.00309)

Blessing AM, Rajapakshe K, Reddy Bollu L, Shi Y, White MA, Pham AH, Lin C, Jonsson P, Cortes CJ, Cheung E et al. 2017 Transcriptional regulation of core autophagy and lysosomal genes by the androgen receptor promotes prostate cancer progression. Autophagy 13 506-521. (https://doi.org/10.1080/15548627.2016.1268300)

Brogden RN, Heel RC, Speight TM \& Avery GS 1978 Cimetidine: a review of its pharmacological properties and therapeutic efficacy in peptic ulcer disease. Drugs 15 93-131. (https://doi.org/10.2165/00003495197815020-00002)

Câmara ML, Almeida TB, de Santi F, Rodrigues BM, Cerri PS, Beltrame FL \& Sasso-Cerri E 2019 Fluoxetine-induced androgenic failure impairs the seminiferous tubules integrity and increases ubiquitin carboxyl-terminal hydrolase L1 (UCHL1): possible androgenic control of UCHL1 in germ cell death? Biomedicine and Pharmacotherapy 109 1126-1139. (https:// doi.org/10.1016/j.biopha.2018.10.034)

Cartier AE, Ubhi K, Spencer B, Vazquez-Roque RA, Kosberg KA, Fourgeaud L, Kanayson P, Patrick C, Rockenstein E, Patrick GN et al. 2012 Differential effects of UCHL1 modulation on alpha-synuclein in PD-like models of alpha-synucleinopathy. PLOS ONE 7 e34713. (https:// doi.org/10.1371/journal.pone.0034713)

Cerri PS \& Sasso-Cerri E 2003 Staining methods applied to glycol methacrylate embedded tissue sections. Micron 34 365-372. (https:// doi.org/10.1016/S0968-4328(03)00098-2) 
Cooper TG 1986 The Epididymis, Sperm Maturation and Fertilization. Berlin: Springer-Verlag. (https://doi.org/10.1007/978-3-642-71471-9)

Cornwall GA 2009 New insights into epididymal biology and function. Human Reproduction Update 15 213-227. (https://doi.org/10.1093/ humupd/dmn055)

Cyr DG, Hermo L \& Laird DW 1996 Immunocytochemical localization and regulation of connexin43 in the adult rat epididymis. Endocrinology 137 1474-1484. (https://doi.org/10.1210/endo.137.4.8625926)

Davis HM, Pacheco-Costa R, Atkinson EG, Brun LR, Gortazar AR, Harris J, Hiasa M, Bolarinwa SA, Yoneda T, Ivan M et al. 2017 Disruption of the $\mathrm{Cx} 43 / \mathrm{miR} 21$ pathway leads to osteocyte apoptosis and increased osteoclastogenesis with aging. Aging Cell 16 551-563. (https://doi. org/10.1111/acel.12586)

de Santi F, Beltrame FL, Hinton BT, Cerri PS \& Sasso-Cerri E 2018 Reduced levels of stromal sex hormone-binding globulin and androgen receptor dysfunction in the sperm storage region of the rat epididymis. Reproduction 155 467-479. (https://doi.org/10.1530/REP-18-0014)

Ding WX, Ni HM, Gao W, Yoshimori T, Stolz DB, Ron D \& Yin XM 2007 Linking of autophagy to ubiquitin-proteasome system is important for the regulation of endoplasmic reticulum stress and cell viability. American Journal of Pathology 171 513-524. (https://doi.org/10.2353/ ajpath.2007.070188)

Doherty J \& Baehrecke EH 2018 Life, death and autophagy. Nature Cell Biology 20 1110-1117. (https://doi.org/10.1038/s41556-018-0201-5)

Domeniconi RF, Souza ACF, Xu B, Washington AM \& Hinton BT 2016 Is the epididymis a series of organs placed side by side? Biology of Reproduction 95 10. (https://doi.org/10.1095/biolreprod.116.138768)

Du ZJ, Cui GQ, Zhang J, Liu XM, Zhang ZH, Jia Q, Ng JC, Peng C, Bo CX \& Shao H 2017 Inhibition of gap junction intercellular communication is involved in silica nanoparticles-induced $\mathrm{H} 9 \mathrm{c} 2$ cardiomyocytes apoptosis via the mitochondrial pathway. International Journal of Nanomedicine 12 2179-2188. (https://doi.org/10.2147/IJN.S127904)

Elfgen V, Mietens A, Mewe M, Hau T \& Middendorff R 2018 Contractility of the epididymal duct: function, regulation and potential drug effects. Reproduction 156 R125-R141. (https://doi.org/10.1530/REP-17-0754)

Eskandari-Shahraki M, Tavalaee M, Deemeh MR, Jelodar GA \& NasrEsfahani MH 2013 Proper ubiquitination effect on the fertilisation outcome post-ICSI. Andrologia 45 204-210. (https://doi.org/10.1111/ j.1439-0272.2012.01330.x)

Ezer N \& Robaire B 2003 Gene expression is differentially regulated in the epididymis after orchidectomy. Endocrinology 144 975-988. (https://doi. org/10.1210/en.2002-220705)

Fan X \& Robaire B 1998 Orchidectomy induces a wave of apoptotic cell death in the epididymis. Endocrinology 139 2128-2136. (https://doi. org/10.1210/endo.139.4.5888)

Firestone GL \& Kapadia BJ 2012 Minireview: regulation of gap junction dynamics by nuclear hormone receptors and their ligands. Molecular Endocrinology 26 1798-1807. (https://doi.org/10.1210/me.20121065)

Florencio-Silva R, Sasso GRS, Sasso-Cerri E, Simões MJ \& Cerri PS 2018 Effects of estrogen status in osteocyte autophagy and its relation to osteocyte viability in alveolar process of ovariectomized rats. Biomedicine and Pharmacotherapy 98 406-415. (https://doi. org/10.1016/j.biopha.2017.12.089)

Foldesy RG \& Bedford JM 1982 Biology of the scrotum. I. Temperature and androgen as determinants of the sperm storage capacity of the rat cauda epididymidis. Biology of Reproduction 26 673-682. (https://doi. org/10.1095/biolreprod26.4.673)

França LR, Leal MC, Sasso-Cerri E, Vasconcelos A, Debeljuk L \& Russell LD 2000 Cimetidine (Tagamet) is a reproductive toxicant in male rats affecting peritubular cells. Biology of Reproduction 63 1403-1412. (https://doi.org/10.1095/biolreprod63.5.1403)

Funder JW \& Mercer JE 1979 Cimetidine, a histamine $\mathrm{H}_{2}$ receptor antagonist, occupies androgen receptors. Journal of Clinical Endocrinology and Metabolism 48 189-191. (https://doi.org/10.1210/jcem-48-2-189)

Gao F, Li G, Liu C, Gao H, Wang H, Liu W, Chen M, Shang Y, Wang L, Shi J et al. 2018 Autophagy regulates testosterone synthesis by facilitating cholesterol uptake in Leydig cells. Journal of Cell Biology 217 2103-2119. (https://doi.org/10.1083/jcb.201710078)

Haendler B, Habenicht UF, Schwidetzky U, Schuttke I \& Schleuning WD 1997 Differential androgen regulation of the murine genes for cysteine-rich Secretory proteins (CRISP). European Journal of Biochemistry 250 440-446. (https://doi.org/10.1111/j.1432-1033.1997.0440a.x)

He W, Wang Q, Xu J, Xu X, Padilla MT, Ren G, Gou X \& Lin Y 2012 Attenuation of TNFSF10/TRAIL-induced apoptosis by an autophagic survival pathway involving TRAF2- and RIPK1/RIP1-mediated MAPK8/ JNK activation. Autophagy 8 1811-1821. (https://doi.org/10.4161/ auto.22145)

Hermo L, Korah N, Gregory M, Liu LY, Cyr DG, D'Azzo A \& Smith CE 2007 Structural alterations of epididymal epithelial cells in cathepsin A - deficient mice affect the blood-epididymal barrier and lead to altered sperm motility. Journal of Andrology 28 784-797. (https://doi. org/10.2164/jandrol.107.002980)

Holtz A, Brennan RG, Battista D \& Terner C 1981 Androgen control of an inhibitory modulator of phosphodiesterase in rat epididymis and prostate. Endocrinology 108 1538-1544. (https://doi.org/10.1210/endo108-4-1538)

Ji CH \& Kwon YT 2017 Crosstalk and interplay between the ubiquitinproteasome system and autophagy. Molecules and Cells 40 441-449. (https://doi.org/10.14348/molcells.2017.0115)

Kaur J \& Debnath J 2015 Autophagy at the crossroads of catabolism and anabolism. Nature Reviews: Molecular Cell Biology 16 461-472. (https:// doi.org/10.1038/nrm4024)

Kempinas WG \& Klinefelter GR 2014 Interpreting histopathology in the epididymis. Spermatogenesis 4 e979114. (https://doi.org/10.4161/2156 5562.2014.979114)

Kleiger G \& Mayor T 2014 Perilous journey: a tour of the ubiquitinproteasome system. Trends in Cell Biology 24 352-359. (https://doi. org/10.1016/j.tcb.2013.12.003)

Klionsky DJ, Abdelmohsen K, Abe A, Abedin MJ, Abeliovich H, Arozena AA, Adachi H, Adams CM, Adams PD, Adeli K et al. 2016 Guidelines for the use and interpretation of assays for monitoring autophagy (3rd edition). Autophagy 12 1-222. (https://doi.org/10.1007/978-3-642-71471-9)

Knigge U, Dejgaard A, Wollesen F, Ingerslev O, Bennett P \& Christiansen PM 1983 The acute and long term effect of the H2-receptor antagonists cimetidine and ranitidine on the pituitary-gonadal axis in men. Clinical Endocrinology 18 307-313. (https://doi.org/10.1111/j.1365-2265.1983. tb03216.x)

Komander D, Clague MJ \& Urbé S 2009 Breaking the chains: structure and function of the deubiquitinases. Nature Reviews: Molecular Cell Biology 10 550-563. (https://doi.org/10.1038/nrm2731)

Kondratskyi A, Kondratska K, Skryma R \& Prevarskaya N 2015 lon channels in the regulation of apoptosis. Biochimica et Biophysica Acta 1848 2532-2546. (https://doi.org/10.1016/j.bbamem.2014.10.030)

Koressaar T \& Remm M 2007 Enhancements and modifications of primer design program Primer3. Bioinformatics Applications Note 23 1289-1291. (https://doi.org/10.1093/bioinformatics/btm091)

Koshimizu JY, Beltrame FL, de Pizzol JP, Cerri PS, Caneguim BH \& SassoCerri E 2013 NF-kB overexpression and decreased immunoexpression of $A R$ in the muscular layer is related to structural damages and apoptosis in cimetidine-treated rat vas deferens. Reproductive Biology and Endocrinology 11 29. (https://doi.org/10.1186/1477-7827-11-29)

Kubecova M, Kolostova K, Pinterova D, Kacprzak G \& Bobek V 2011 Cimetidine: an anticancer drug? European Journal of Pharmaceutical Science 42 439-444. (https://doi.org/10.1016/j.ejps.2011.02.004)

Kwon J 2007 The new function of two ubiquitin C-terminal hydrolase isozymes as reciprocal modulators of germ cell apoptosis. Experimental Animals 56 71-77. (https://doi.org/10.1538/expanim.56.71)

Kwon J, Wang YL, Setsuie R, Sekiguchi S, Sakurai M, Sato Y, Lee WW, Ishii Y, Kyuwa S, Noda M et al. 2004a Developmental regulation of ubiquitin C-terminal hydrolase isozyme expression during spermatogenesis in mice. Biology of Reproduction 71 515-521. (https://doi.org/10.1095/ biolreprod.104.027565)

Kwon J, Wang YL, Setsuie R, Sekiguchi S, Sato Y, Sakurai M, Noda M, Aoki S, Yoshikawa Y \& Wada K 2004b Two closely related ubiquitin C-terminal hydrolase isozymes function as reciprocal modulators of germ cell apoptosis in cryptorchid testis. American Journal of Pathology 165 1367-1374. (https://doi.org/10.1016/S0002-9440(10)63394-9)

Kwon J, Sekiguchi S, Wang YL, Setsuie R, Yoshikawa Y \& Wada K 2006 The region-specific functions of two ubiquitin $\mathrm{C}$-terminal hydrolase isozymes along the epididymis. Experimental Animals 55 35-43. (https:// doi.org/10.1538/expanim.55.35) 
Lee NPY, Leung KW, Wo JY, Tam PC, Yeung WSB \& Luk JM 2006 Blockage of testicular connexins induced apoptosis in rat seminiferous epithelium. Apoptosis 11 1215-1229. (https://doi.org/10.1007/s10495-006-6981-2)

Li L, Tao Q, Jin H, van Hasselt A, Poon FF, Wang X, Zeng MS, Jia WH, Zeng YX, Chan ATC et al. 2010 The tumor suppressor UCHL1 forms a complex with p53/MDM2/ARF to promote p53 signaling and is frequently silenced in nasopharyngeal carcinoma. Clinical Cancer Research 16 2949-2958. (https://doi.org/10.1158/1078-0432.CCR-093178)

Li WR, Chen L, Chang ZJ, Xin H, Liu T, Zhang YQ, Li GY, Zhou F, Gong YQ, Gao ZZ et al. 2011 Autophagic deficiency is related to steroidogenic decline in aged rat Leydig cells. Asian Journal of Andrology 13 881-888. (https://doi.org/10.1038/aja.2011.85)

Liu Y, Fallon L, Lashuel HA, Liu Z \& Lansbury PT 2002 The UCH-L1 gene encodes two opposing enzymatic activities that affect alpha-synuclein degradation and Parkinson's disease susceptibility. Cell $111209-218$. (https://doi.org/10.1016/s0092-8674(02)01012-7)

Lydka M, Kopera-Sobota I, Kotula-Balak M, Chojnacka K, Zak D \& Bilinska B 2011 Morphological and functional alterations in adult boar epididymis: effects of prenatal and postnatal administration of flutamide. Acta Veterinaria Scandinavica 53 12. (https://doi.org/10.1186/17510147-53-12)

Mariño G, Niso-Santano M, Baehrecke EH \& Kroemer G 2014 Selfconsumption: the interplay of autophagy and apoptosis. Nature Reviews: Molecular Cell Biology 15 81-94. (https://doi.org/10.1038/nrm3735)

Moore HD \& Bedford JM 1979 Short-term effects of androgen withdrawal on the structure of different epithelial cells in the rat epididymis. Anatomical Record 193 293-311. (https://doi.org/10.1002/ar.1091930209)

Oliveira RL, Parent A, Cyr DG, Gregory M, Mandato CA, Smith CE \& Hermo L 2016 Implications of caveolae in testicular and epididymal myoid cells to sperm motility. Molecular Reproduction and Development 83 526-540. (https://doi.org/10.1002/mrd.22649)

Orgebin-Crist MC, Danzo BJ \& Davies J 1975 Endocrine control of the development and maintenance of sperm fertilizing ability in the epididymis. In Male Reproductive System, 1st ed., pp. 319-338. Eds RO Greep \& D Hamilton. Washington, D.C.: American Physiological Society.

Ouyang C, You J \& Xie Z 2014 The interplay between autophagy and apoptosis in the diabetic heart. Journal of Molecular and Cellular Cardiology 71 71-80. (https://doi.org/10.1016/j.yjmcc.2013.10.014)

Park JH, Lee JE, Shin IC \& Koh HC 2013 Autophagy regulates chlorpyrifosinduced apoptosis in SH-SY5Y cells. Toxicology and Applied Pharmacology 268 55-67. (https://doi.org/10.1016/j.taap.2013.01.013)

Pukaß K \& Richter-Landsberg C 2015 Inhibition of UCH-L1 in oligodendroglial cells results in microtubule stabilization and prevents $\alpha$-synuclein aggregate formation by activating the autophagic pathway: implications for multiple system atrophy. Frontiers in Cellular Neuroscience 9 163. (https://doi.org/10.3389/fncel.2015.00163)

Reid BL \& Cleland K 1957 The structure and function of the epididymis. 1. The histology of the Rat epididymis. Australian Journal of Zoology 5 223-246. (https://doi.org/10.1071/ZO9570223)

Robaire B \& Hamzeh M 2011 Androgen action in the epididymis. Journal of Andrology 32 592-599. (https://doi.org/10.2164/jandrol.111.014266)

Robaire B \& Hermo L 1988 Efferent ducts, epididymis and vas deferens: structure, functions, and their regulation. In The Physiology of Reproduction, 1st ed., pp. 999-1080. Eds E Knobil \& J Neill. New York: Raven Press.

Robaire B \& Hinton BT 2002 Epididymis: From Molecules to Clinical Practice: A Comprehensive Survey of the Efferent Ducts, the Epididymis, and the Vas Deferens. New York: Springer. (https://doi.org/10.1007/9781-4615-0679-9)

Robaire B \& Hinton BT 2015 The epididymis. In Knobil and Neill's Physiology of Reproduction, 4th ed., pp. 1071-1148. Eds T Plant \& A Zeleznik. San Diego: Academic Press. (https://doi.org/10.1016/B978-012-397175-3.00017-X)

Roberts KP, Hoffman LB, Ensrud KM \& Hamilton DW 2001 Expression of crisp-1 mRNA splice variants in the rat epididymis, and comparative analysis of the rat and mouse crisp- 1 gene regulatory regions. Journal of Andrology 22 157-163.

Santamaria L, Martin R, Paniagua R, Fraile B, Nistal M, Terenghi G \& Polak JM 1993 Protein gene product 9.5 and ubiquitin immunoreactivities in rat epididymis epithelium. Histochemistry 100 131-138. (https://doi. org/10.1007/bf00572899)

Sasso-Cerri E \& Cerri PS 2008 Morphological evidences indicate that the interference of cimetidine on the peritubular components is responsible for detachment and apoptosis of Sertoli cells. Reproductive Biology and Endocrinology 6 18. (https://doi.org/10.1186/1477-7827-6-18)

Sasso-Cerri E \& Miraglia SM 2002 In situ demonstration of both TUNELlabeled germ cell and Sertoli cell in the cimetidine-treated rats. Histology and Histopathology 17 411-417. (https://doi.org/10.14670/ $\mathrm{HH}-17.411)$

Scragg JL, Jones RD, Channer KS, Jones TH \& Peers C 2004 Testosterone is a potent inhibitor of L-type Ca2+ channels. Biochemical and Biophysical Research Communications 318 503-506. (https://doi.org/10.1016/j. bbrc.2004.04.054)

Scragg JL, Dallas ML \& Peers C 2007 Molecular requirements for L-type $\mathrm{Ca}^{2+}$ channel blockade by testosterone. Cell Calcium 42 11-15. (https:// doi.org/10.1016/j.ceca.2006.11.003)

Shaid S, Brandts CH, Serve H \& Dikic I 2013 Ubiquitination and selective autophagy. Cell Death and Differentiation 20 21-30. (https://doi. org/10.1038/cdd.2012.72)

Shi Y, Han JJ, Tennakoon JB, Mehta FF, Merchant FA, Burns AR, Howe MK, McDonnell DP \& Frigo DE 2013 Androgens promote prostate cancer cell growth through induction of autophagy. Molecular Endocrinology 27 280-295. (https://doi.org/10.1210/me.2012-1260)

Spence RW \& Celestin LR 1979 Gynaecomastia associated with cimetidine. Gut 20 154-157. (https://doi.org/10.1136/gut.20.2.154)

Sujarit S \& Pholpramool C 1985 Enhancement of sperm transport through the rat epididymis after castration. Journal of Reproduction and Fertility 74 497-502. (https://doi.org/10.1530/jrf.0.0740497)

Sutovsky P 2003 Ubiquitin-dependent proteolysis in mammalian spermatogenesis, fertilization, and sperm quality control: killing three birds with one stone. Microscopy Research and Technique 61 88-102. (https://doi.org/10.1002/jemt.10319)

Sutovsky P, Moreno R, Ramalho-Santos J, Dominko T, Thompson WE \& Schatten G 2001 A putative, ubiquitin-dependent mechanism for the recognition and elimination of defective spermatozoa in the mammalian epididymis. Journal of Cell Science 114 1665-1675.

Tang M \& Fang J 2017 TNF- $\alpha$ regulates apoptosis of human vascular smooth muscle cells through gap junctions. Molecular Medicine Reports 15 1407-1411. (https://doi.org/10.3892/mmr.2017.6106)

Ummanni R, Jost E, Braig M, Lohmann F, Mundt F, Barett C, Schlomm T, Sauter G, Senff T, Bokemeyer C et al. 2011 Ubiquitin carboxyl-terminal hydrolase 1 (UCHL1) is a potential tumour suppressor in prostate cancer and is frequently silenced by promoter methylation. Molecular Cancer 10 129. (https://doi.org/10.1186/1476-4598-10-129)

Untergasser A, Cutcutache I, Koressaar T, Ye J, Faircloth BC, Remm M \& Rozen SG 2012 Primer3-new capabilities and interfaces. Nucleic Acids Research 40 e115. (https://doi.org/10.1093/nar/gks596)

Van Thiel DH, Gavaler JS, Heyl A \& Susen B 1987 An evaluation of the antiandrogen effects associated with $\mathrm{H} 2$ antagonist therapy. Scandinavian Journal of Gastroenterology: Supplement 136 24-28. (https://doi. org/10.3109/00365528709094482)

Vinken M, Vanhaecke T, Papeleu P, Snykers S, Henkens T \& Rogiers V 2006 Connexins and their channels in cell growth and cell death. Cellular Signalling 18 592-600. (https://doi.org/10.1016/j. cellsig.2005.08.012)

Wang C, Lai CL, Lam KC \& Yeung KK 1982 Effect of cimetidine on gonadal function in man. British Journal of Clinical Pharmacology 13 791-794. (https://doi.org/10.1111/j.1365-2125.1982.tb01867.x)

Wang WJ, Li QQ, Xu JD, Cao XX, Li HX, Tang F, Chen Q, Yang JM, Xu ZD \& Liu XP 2008 Over-expression of ubiquitin carboxy terminal hydrolase-L1 induces apoptosis in breast cancer cells. International Journal of Oncology 33 1037-1045. (https://doi.org/10.3892/ijo_00000092)

Wang YL, Liu W, Sun YJ, Kwon J, Setsuie R, Osaka H, Noda M, Aoki S, Yoshikawa Y \& Wada K 2006 Overexpression of ubiquitin carboxylterminal hydrolase L1 arrests spermatogenesis in transgenic mice. Molecular Reproduction and Development 73 40-49. (https://doi. org/10.1002/mrd.20364)

Winters SJ, Banks JL \& Loriaux DL 1979 Cimetidine is an antiandrogen in the rat. Gastroenterology 76 504-508. (https://doi.org/10.1016/S00165085(79)80217-6) 
Wong PY \& Yeung CH 1978 Absorptive and secretory functions of the perfused rat cauda epididymidis. Journal of Physiology 275 13-26. (https://doi.org/10.1113/jphysiol.1978.sp012174)

Wong PYD, Au CL \& Ngai HK 1978 Electrolyte and water transport in rat epididymis; its possible role in sperm maturation. International Journal of Andrology 1 608-628.

Yan C, Huo H, Yang C, Zhang T, Chu Y \& Liu Y 2018 Ubiquitin C-terminal hydrolase $\mathrm{L} 1$ regulates autophagy by inhibiting autophagosome formation through its deubiquitinating enzyme activity. Biochemical and Biophysical Research Communications 497 726-733. (https://doi. org/10.1016/j.bbrc.2018.02.140)

Zhang X, Guo L, Niu T, Shao L, Li H, Wu W, Wang W, Lv L, Qin Q, Wang F et al. 2014 Ubiquitin carboxyl terminal hydrolyase L1-suppressed autophagic degradation of p21 WAF1/Cip1 as a novel feedback mechanism in the control of cardiac fibroblast proliferation. PLOS ONE 9 e94658. (https://doi.org/10.1371/journal.pone.0094658)

Received 30 September 2019

First decision 29 October 2019

Revised manuscript received 13 March 2020

Accepted 19 March 2020 